\title{
2
}

\section{THE ASSAULT OF FINANCIAL FUTURES ON THE REST OF TIME}

\author{
Timo Walter and Leon Wansleben
}

\section{Introduction}

In Alexander Kluge's movie Der Angriff der Gegenwart auf die übrige Zeit (The Assault of the Present on the Rest of Time), people live in a 'distended present' (Kluge et al. 1990: passim): faced with uncertain - personal and societal - futures, they are unable to make lasting decisions and remain trapped in an unending present. In this contribution, we discuss another 'assault on the rest of time' that was just in the making when Kluge's film appeared in 1985 - namely, the ways in which finance shapes and formats the politics of the future. Our central tenet is that, far from providing an engine for imagining substantive futures that guide (collective) actions, finance 'consumes' forecasts, plans or visions. They serve as mere signals (Langenohl and Wetzel 2011), fuelling an increasingly short-term (Montagne 2009), febrile hunt for novelties from which profit can be generated by beating others to it.

In (economic) theory, prices will oscillate - more or less - evenly around the expected 'intrinsic' value in response to incoming signals, so that 'the time average of an observable [is] equal to its expectation value' (Peters 2019: 1216). Based on this statistical premise of 'ergodicity', there can be no fundamental discontinuity between future, on the one hand, and past and present, on the other - so that rational inter-temporal calculation and expectations become possible (Beckert and Bronk 2018: 18-20). ${ }^{1}$ As the formal models and calculative devices through which economic agents project and imagine the future are built on these assumptions, the ergodic continuity between past, present and future effectively becomes part of the background frame within which signals about the future are given meaning and translated in the present. We thus suggest that the temporality of contemporary finance is at odds with modernist conceptions of futurity as involving an epistemic 'back and forth' between a given present and an open future, out of which emerge contingency, freedom and choice (Esposito 2004; Luhmann 1976). The 
'future' towards which finance is oriented (Arrow 1978) is constantly collapsed into the present through an ongoing process of 'pricing in' the future and rendering it calculable according to an a-temporal space of possibilities. For modern finance, the future has become a useful means of acting in the present, rather than an ontologically distinct state that we imagine and construct based on joint imaginations as we proceed towards it from the present. We develop this point by discussing the case of derivatives markets. We show how derivatives markets depend directly on the assumption of a 'synchronicity' of present and future, built directly into the central valuation device on which the functioning of these markets depends - the so-called Black-Scholes-Merton formula. We extend this argument in the second part of our contribution, where we describe how central banks have developed a financeoriented and finance-based 'governmentality' (Foucault 2007[1978]). Under this regime, central banks really do not govern future inflation, but present expectations of future inflation as expressed in the 'yield curve' and built into interest rate derivatives. We suggest that the use of rational expectations models that construe the future as 'conserved' within an ergodic, a-temporal world allows central banks to ignore possible 'random' fluctuations in actual inflation and concentrate on the internal calibration of present expectations of future inflation as the sole criterion for monetary policy success. We show that this 'assault' of present expectations on a future that never becomes actualised was an important factor in the run-up to the crisis of 2007-2009. Central banks have facilitated forms of financial valuation that rely on key fictions of an ergodic world (in particular the 'natural' interest rate), by stabilising the expectational parameters which manifest these fictions, and have thus helped to black-box uncertainties. The crisis itself, and post-crisis interventions, have not led to a 'reckoning' with a different temporality, but have activated various support mechanisms and new policy tools (e.g. 'forward guidance') that shield and maintain this 'practical fiction' and the 'infrastructure' (Star and Ruhleder 1996) of an ergodic world for contemporary finance. What has become clearer, though, is that the particular constellations of policy institutions and financial markets found in contemporary capitalism do not support economic prosperity and sustainability for society as a whole.

\section{The ergodic world of 'quantitative' finance}

Compared to the embedded, 'boring finance' of the period from the 1950s to the 1980 s, in the contemporary financial system the contingency of all financial activity with regard to the future has become much more visible. In particular, the 'openness of the future' (Beckert 2015: 35ff), and the problem that an open future is necessarily contingent and therefore 'fundamentally uncertain' (Knight 1921) has moved centre-stage in discussions about contemporary finance. Whereas, in the 'golden age of capitalism' (Marglin and Schor 2000), finance lived well by the '3-6-3' rule (charge a 3 per cent mark-up on credit over the 3 per cent interest paid out on deposits and be off to the golf course at 3pm) (Walter 2006), the de-regulation and financial innovation that started in the 1970s (Helleiner 1994) has turned the future 
into an explicit epistemic problem. As a result, financial (and economic) activity has become much more directly dependent on the elaboration of 'imagined futures' and calculative 'instruments of imagination' for the coordination of expectations (Beckert 2016: 216ff.). Since the liquidity and stability of markets hinge directly on the continuity of valuations (and the knowledge underpinning them) (Carruthers and Stinchcombe 1999) this means that these epistemic practices and calculative instruments - and the joint expectations of the futures that they help construct have become central to the functioning of contemporary finance.

It has therefore become common for both practitioners and observers to understand contemporary finance as revolving around the problem of mitigating the fundamental epistemic uncertainty of a future that is open and contingent. In this view, finance has become a primary site for 'acting in an uncertain world' (Callon et al. 2009), where market participants learn to forecast and imagine such futures through calculative devices and/or hedge against uncertainties using various financial tools. The crucial significance of finance in modern society thus stems from its role as an institution that allows social actors to cope, manage and live with an uncertain future, and to render this open future as a space of possibilities - for speculation, investment, hedging, insurance, betting etc.

There is, however, some reason to be cautious about the notion that uncertainty in finance is - primarily - a function of the irreducible gap between present futures and actual future presents. The historian Reinhart Koselleck (1989) has theorised this gap as being a result of historical experiences that have led actors to distinguish these two distinct forms of 'future': the future as imagined in the present ('present future') and future presents, i.e. future states of the world when they (have) become present, or actualised. However, this decidedly modern form of temporality is not the one that reigns in contemporary finance.

To argue this point, we need to look at precisely how epistemic accuracy of expectations about the future present matters in finance. As John Maynard Keynes and Hyman Minsky pointed out long ago, the openness of the future manifests itself as an 'economic survival constraint': false or inaccurate present futures are costly, or even life-threatening, to economic units, if investments fail. For that reason, Keynes and Minsky thought that as uncertainty is more directly and intensively felt, economic units will avoid tying down their wealth in risky investments and will protect themselves against adverse risks by stocking up on liquid reserves.

The key characteristic of this uncertainty - the uncertainty of having enough liquid means to meet upcoming obligations - is that it cannot readily be made measurable: it depends on the behaviour of various other actors (e.g. money market lenders) and the various feedback processes by which one's own and others' decisions (e.g. asset sales) affect the state of the financial system as a whole. However, as central banks have encouraged and supported financial markets' reliance on 'ergodic fictions' for valuation and risk management, this uncertainty has ceased to feature in the regular calculations and strategies of financial actors and in the structures of the financial system, giving way to a world in which actors act most of the time as if market liquidity and stable asset prices will be maintained indefinitely. 
To understand how and why, we need to decipher the role played by rational expectations (as both a category of practice and a theory) in contemporary finance. Discounting expected future returns to calculate an asset's present value requires knowledge of the future development of macroeconomic variables (such as growth, interest rates or inflation, etc.) which, in models and formulas derived from rational expectations economics, shape this present value, as joint expectations about such parameters become widely embedded in valuations (Bryan and Rafferty 2006). Such parameters come to define a 'normality' as background to and a condition of asset valuations, with market actors closely tracking any anomalies that might affect asset values (Christophers 2017; Zaloom 2009). This 'normality' has become an intrinsic background for the joint structures of knowledge that secure the continuity of valuations and market transactions, and thus undergird the liquidity and stability of 'market-based finance' (Hardie and Howarth 2013). This background establishes a (calculative and epistemic) continuity between the present and the future, built directly into the fabric of financial markets, against which more narrow present futures can be elaborated, processed, adopted or discarded. The intense concern with the future in contemporary finance is thus made possible by this 'synchronist' (Langenohl 2018) background, which anchors the impressive array of instruments of imagination in an a-temporal skeletal structure upon which the validity of any calculation of present futures depends.

This ergodic conception of time (Kirstein 2015) is important for contemporary finance particularly in those contexts in which the respective parameters are directly incorporated into the markets' valuation devices. A case in point are the derivatives markets, which do not value and trade normal financial assets (such as stocks or currencies) but which are based on contracts through which parties directly wager on future prices of underlying assets in relation to specific future events. Derivatives thus express imagined futures and the valuations they imply (through discounting), without the need to possess or actually trade underlying assets. This might suggest that, if anywhere, it is in the derivatives markets that actors care about whether their present futures actually become future presents at some point in time. But this is not how valuation and pricing works in these markets, which are based on the common valuation infrastructure that relies on the Black-Scholes-Merton formula (Watson 2007; MacKenzie and Millo 2003; Black and Scholes 1973). With this formula, traders no longer focus on particular events and future presents as they arrive but instead trade what is called 'volatility' - a measure of the variability of prices over time that is dependent on such variation remaining ergodic (Davidson 1982). Using this calculative tool, participants thus engage in a market process in which particular events and risks are subsumed with regards to a 'synchronic' background system of valuation and pricing.

The validity and applicability of the Black-Scholes-Merton formula is thus premised on this assumption of a fundamentally static and continuous world that does not undergo any fundamental substantive changes. In this world, present futures are nothing but short-lived inputs or signals that generate possibilities for arbitrage, but do not affect the static background continuity that undergirds the system. However, in the case of 'black swan' events (Taleb 2007) - that is, when highly improbable 
'tail-end' events in a probability distribution occur - a system of valuations premised on ergodicity becomes incoherent, leading markets to freeze. As Donald MacKenzie (2004; MacKenzie and Millo 2003) has shown, the 1987 stock market crash drove home the limits of this ergodic depiction of temporality, and practitioners adjusted their Black-Scholes-Merton pricing ad hoc and modified the price curve for options so that longer-termed options now include an uncertainty premium (the so-called 'volatility smile' or 'skew') on top of their 'ergodic' price.

Derivatives markets thus highlight particularly clearly how the synchronist background against which financial valuation operates mitigates uncertainty, not by encouraging actors to reckon with an uncertain future but by excluding the possibility that the future might be discontinuous with the present (in aggregate terms) in any radical sense. For the continuous functioning of financial markets, it is more important to uphold a stable background of expectations than to know the future accurately. The synchronist frame operatively decouples actions taken in reaction to and in terms of present futures from the actual future present(s) that come to pass.

Many observers and practitioners have noted how this separation from this calculative background has made the sequential processing of transitory present futures at the 'surface' of the market almost ritualistic (e.g. LiPuma 2017; Ayache 2016). The unfolding of present futures is largely irrelevant to, and does not feed into, the static expectations about the future encoded in this background, which are reasserted or 'performed' anew with every transaction that makes use of instruments of valuation or calculation derived from rational expectations models (cf. LiPuma 2017). Derivatives markets thus form the extreme end of a continuum but highlight the logical conditions of why the liquidity and stability of modern financial markets depends on this calculative background. They illustrate why the accuracy of expectations is not actually put to the test (or at least only idiosyncratically, for individual traders) as long as markets can operatively hold on to this 'useful' fiction of a continuous, normal and ergodic world. As a result, for modern finance the future itself is continuously 'ontologically absent' (Law and Urry 2004): it is a horizon of possibilities that provides inputs for arbitrage, but must remain invisible at the level of the constitutive fiction of the never-changing future on which market stability rests.

The modern financial system is thus based on 'wilful' or 'strategic ignorance' (McGoey 2012) of the future present as a constitutive principle: excluding the possibility of substantive discontinuities between present and future is what enables the 'transformation of uncertainty into risk' (Carruthers 2013) and secures the possibility of rational calculation and action in markets in the present. As market coordination increasingly depends on the construction, projection and diffusion of 'commensurable' (Espeland and Stevens 1998) present futures, this common background has gained in importance. It allows translating present futures into numeric prices, and thus is central to securing the congruence of expectations (about present and future prices) in markets. The financial system's ability to process information about the future thus depends on the continuous operative denial of the openness of this very future. Whatever individual actors might think privately, at the level of the market public, uncertainty must not be allowed to manifest itself, but must continuously be absorbed 
and neutralised - as a precondition for the system's ability to process any signals about the future that might entail (limited) re-valuations and price changes at all.

Evidently, excluding the possibility of a fundamental discontinuity of the economic present and future mathematically does not protect financial actors from suffering the consequences of being (collectively) wrong. However, Minsky has shown, with his now famous 'financial instability hypothesis' (Minsky 1980), that if central banks are actively working to protect markets from a breakdown of the fictional continuity and the 'normal market conditions' it enables, they are effectively removing the survival constraint on financial institutions. In other words, they protect market actors from ever having to face fundamental discontinuity, allowing them instead to continue processing present futures without concerning themselves with their accuracy. As Minsky pointed out, by continuously neutralising the effects of fundamental dissonances about the future, and shoring up 'normal' assumptions about the future in order to secure the 'normal' operations of the system, one also abolishes any incentives to look out for, and be prepared for, the possibility of fundamentally different futures, blanking out underlying systemic uncertainties.

The more market actors are assured that normal market conditions will continue (indefinitely) into the future, the more the future becomes a 'useful fiction', that is continuously presupposed but must never actually affect the normal operations of the system. As we shall see in the next section, central banks' efforts to gain 'infrastructural power' (Walter and Wansleben 2019; Braun and Gabor 2019; Braun 2018a), by seeking to develop technologies for influencing financial markets (and the economy) by 'governing through expectations' (Wansleben 2018; Braun 2015), have become directly complicit with this specific temporality of modern finance.

\section{Hegemonic futures in financialised capitalism}

The role of an ergodic world as a calculative background for market coordination has gained increased general societal and economic importance through processes of financialisation. Financialisation can be used as a descriptive term to depict how the size of finance has grown compared to the rest of the economy (Stockhammer 2008), how corporations shift their sources of profit from production to financial activities (Krippner 2005) and/or how households in Western economies have become increasingly entangled in financial markets, as mortgage holders, employees with private pension plans, owners of life insurance products and the like (van der Zwan 2014; Davis 2009). We use the concept here in a related but somewhat different sense. Our interest is in how the logics of coordination that are reliant on particular conceptions of futurity become dominant in regard to the ways in which capitalist democracies are rendered governable. We are thus interested in reconstructing a particular 'governmentality' that is not exhaustively described with regards to shareholder value, speculative identities or even particularistic elite interests, but that concerns the fundamental ways in which capitalism is stabilised as a social system. This sounds like a rather grand claim but we believe there is strong evidence for the rise of finance as a new governmentality, which is closely 
associated with the emergence of central banks as the most powerful governors in advanced capitalist states.

The specific proposition that we make is that central banks have contributed to transcending the role of contemporary finance by tying their own practices of macroeconomic policy-making to this particular realm (Krippner 2011). We will here limit this discussion to the symbolic-communicative dimension of central banks' governing - a topic that has raised much interest in sociological (Braun 2015) and anthropological (Holmes 2013) research. The innovation identified by these scholars is that central bankers have learned to govern monetary developments by communicating their intentions and planned interventions; the markets, reacting to such signals, then are thought to adapt accordingly, performatively bringing about the effects that the central banks intended to obtain. The point that we want to elaborate on here is that such 'performative' central banking should not be considered as a neutral strategy for achieving legitimate political objectives like low inflation and stable growth. The respective practices of governing rather require that central banks align their interventions with the structure of financial markets, and with the particular mechanisms through which these markets project their 'present futures'.

This firstly entails a subtle, but important, shift in the very object of governing. The sociological argument underlying the idea of 'expectational governance' is that central banks can control price-setting in the economy by influencing the expectations that economic actors have with regard to changes in the inflation rate (Beckert 2016). When these actors - like wage bargainers - expect inflation to remain stable, they will be more moderate with their wage claims and their markup pricing, and thereby produce the low inflation rates that they assume will prevail. This self-confirmatory logic is intuitive. But surveys have shown time and again that the general public's expectations are relatively fickle and that inflation rates can be influenced by various factors, not all of which are expectational (Lombardelli and Saleheen 2003). Central bankers have resolved these uncertainties and problems by redefining what they actually control: not inflation itself but inflation expectations, as incorporated into financial markets' calculations and operations. The assumption is that, as long as these specific expectations remain stable, it does not matter that prices actually fluctuate somewhat, or that most people do not have a good understanding of how inflation will evolve. As a consequence, cognitive and normative expectations inherent in markets, rather than the demands, claims and ideas from the broader economy, become the linchpin for assessing central bankers' success, and for orienting their macroeconomic policies. Financial market expectations thus have become central banks' primary objects of governing: all that matters is that financial market prices - primarily long-term interest rates - reflect expectations that inflation will remain stable and low.

This reorientation to markets was well articulated by Ben Bernanke - an architect of inflation targeting - who claimed that 'monetary policy is a cooperative game. The whole point is to get financial markets on our side and for them to do some of our work for us' (cited in Mallaby 2017: 612, our emphasis). In other words, central banks rely on financial markets to assume a hegemonic role in defining 
economic futures more generally, and they reinforce this hegemony by aligning their communications with the specific logics of these markets.

This brings us to a second dimension of such finance-oriented expectation coordination - the fictitious elimination of radical uncertainty and the simulation of an ergodic socio-economic system with stable parameters within which financial expansion can unfold. To illustrate this point, let us imagine a central bank that has some expertise in finance and the economy, but that only imprecisely and 'with uncertainty' knows how the economy will evolve going forward - what the level of employment will be, how much output is going to be produced, how the employment level and output are going to relate to the productive capacities of the economy, how such interactions will affect the price level - not to speak of the uncertainties arising from developments in asset and credit markets that affect banking, household wealth, productive facilities, consumer spending etc. Such a semi-knowledgeable, semi-ignorant central bank would decide on interest rates in somewhat unpredictable ways, and there may be many occasions in which markets are taken by surprise.

However, with the introduction of inflation targeting since the late 1980s, it became imperative to create far more predictability between central banks and markets. This made it necessary to render invisible these fundamental uncertainties faced by policy-makers (Walter and Wansleben 2019). Accordingly, central bankers increasingly drew on a model of the economy in which uncertainty was in fact not an important factor (Woodford 2009). Equilibrium output, the non-inflationary rate of employment and the natural rate of interest were all assumed to be knowable variables that could orient policy-making and its coordination with financial markets. Accordingly, there were fewer and 'fewer occasions on which the authorities' decisions - as opposed to the underlying economic developments - cause[d] uncertainty in the markets' (Butler and Clews 1997: 48) - which was perceived as a virtue of the inflation targeting regime.

In other words, the tools and techniques of macroeconomic policy championed by central banks have enhanced and strengthened the 'normality expectations' undergirding valuations in financial markets. This has then reinforced the expansionary dynamics of finance, leading to a proliferation of contracts (e.g. of securitised assets), market relations and balance sheets that presuppose an unchanging macroeconomic background structure upon which financialisation rests (Nesvetailova 2015; Mehrling 2011). Particular features of financialisation, such as the interrelated expansion of asset and money markets, rely on these normality expectations, and more generally on the notion that central banks will maintain stability in regard to all major macroeconomic variables (inflation, interest rates) that are relevant for financial markets. However, as the transatlantic financial crisis of 2007-2009 has brought home, the 'success' of central banks' coordination with finance should not be confused with the development of reliable and sustainable ways of governing capitalist democracies. Indeed, the events in these years rather demonstrated that the self-validation between policy-makers and market actors had become dissociated from the actual socio-economic structures - precarious labour market situations, debt pyramids etc. - to which their macroeconomic models and valuation practices 
purported to refer (e.g. Fligstein et al. 2017). However, this has not led to a fundamental questioning of the governmentality regime associated with financialisation. Rather, central banks' 'unconventional' expansionary monetary policies since 2009 reflect a reinforcement of finance-oriented and finance-centred policy-making (Braun 2018b). The central aim of post-crisis policy has been to reinstate confidence within finance about the indefinite continuity of 'normal' patterns of output, inflation, interest rates etc., with the intended effect of inducing market actors to re-engage in investments and credit provision, which are believed to generate growth. Finance thus remains at the centre of macroeconomic governance and thus maintains its privileged role in 'mature' capitalism.

To be fair, there has been some critical discussion among expert economists about the adverse consequences of such regimes. For instance, Tobias Adrian and Nelly Liang write that:

Monetary policy works though financial conditions on expected economic outcomes, but risks to financial stability involve potential tail risks. The tail risks to future macroeconomic outcomes manifest only in some states of the world, when adverse shocks are realized. These dimensions are important because they greatly complicate efforts to incorporate financial stability in the determination of monetary policy. Policy makers would need to look beyond expected conditions for downside risks that arise with uncertain probability in the future (2016: 4).

Yet there seems to be little appetite among policy-makers to take seriously these adverse financial stability effects, not to speak of the broader societal problems, which arise from the current finance-oriented governance regime.

\section{Conclusion}

Up until now the highly problematic 'politics of the future' entailed by the characteristic temporality of modern finance, and its widening implications due to financialisation, have by-and-large passed under the radar (but see, Adkins 2018; Langenohl 2018; 2007). While our focus in this chapter has been on how technological, epistemic and political infrastructures make this temporality more durable and lend it a degree of invisibility, the concerns we would like to raise are related to these - for the most part sociological and anthropological - 'diagnostics of the present'.

To be sure, the fragilities in the financial system that result from the continuous need to stabilise the 'discounted' fictive future values in the present have been widely noted (Mehrling 2011; Nesvetailova 2007), but they have only rarely been linked to the peculiar temporalities of modern finance (but see LiPuma 2017). More commonly, financial fragility is instead interpreted as an issue of complexity to be addressed by increasing the transparency of markets, and in particular by reducing the epistemic uncertainty that this complexity generates with regard to the system's own future (Gräbner and Kapeller 2015; Cooper 2011). 
Following from our argument, the present attempts, through regulation and monetary policy, to manage and contain the complexity of contemporary finance may, paradoxically, contribute to instability if the main aim remains to stabilise the working fiction of an ergodic, 'timeless' temporality on which financial markets are premised. This ergodic normality has become the very foundation of the calculability of financial values (Peters 2019), its commensurability across assets and markets, and thus the liquidity and stability of those markets themselves. This is all the more the case as there has been a marked, global trend towards market-based finance (Murau 2017; Gabor 2016) in which the ability to shift assets in markets has become the basis of liquidity (Mehrling 2011), increasing the systemic risk entailed by disruptions to this frame of calculability. The need to protect this temporality, the frame of calculability and structure of valuations it undergirds, forces central banks into continuing their role of reinsurer of systemic risk and market-maker of last resort that contributed to the 2007-2009 crisis, backstopping the value of a widening pool of - only seemingly - 'liquid' assets (Mehrling 2011; Borio and White 2004). The 'unconventional' monetary policies of quantitative easing pursued by central banks around the world since 2008 are even named so as to evoke their rationale of restoring and safeguarding the technical presuppositions of 'normal' or 'conventional' forms of governability. Likewise, the 'macro-prudential' financial regulation that has come to dominate regulatory debates (Coombs 2017; Baker 2013) attempts to correct the fragilities created by the 'distended present' of modern finance by increasing the transparency of risks (e.g., through stress tests), creating resiliences and facilitating 'efficient' risk-sharing within the financial system. Despite some undeniable innovations at the level of technical frameworks and instruments at its disposal since 2008-2009, monetary policy thus continues to be geared towards ergodicity as its operative framework. 'Macro-pru' and unconventional policies aim, first and foremost, at restoring and protecting normal conditions in financial markets, as a platform for effective monetary policy. This normality is conceived of in ergodic terms and observed through (mathematical) models that are premised on ergodicity. Deviations from normality thus become an impediment to be neutralised in order to secure the inter-temporal consistency and effectiveness of monetary policy rather than being seen as (potentially) indicative of (fundamental) uncertainties of which market actors (and central banks!) would need to take heed, and which might require adjustments to their calculative strategies. Instead, central banks proactively seek to restore 'quasi-ergodic' conditions in financial markets, by reducing what they perceive as market imperfections that prevent the even inter-temporal dissemination of monetary policy signals. However, in combating manifestations of uncertainty as anomalies that stand in the way of monetary policy operations premised on the ergodicity of finance and the economy, central banks are sterilising the very signs that the future may indeed substantively differ from past and present. Their interventions provide financial markets with a working fiction of an ergodic world, and, rather than removing vulnerabilities, they counteract the very processes through which collective sense-making could solidify into effectively constraining price signals - until, that is, the next crisis... 


\section{Note}

1 In technical terms, '[e]rgodicity is fulfilled, if the time average of a system or process equals its ensemble average. The time average is the average of one observed trajectory or realisation of a process (one time series). The ensemble average is the average over every possible state of a system' (Kirstein 2015: 1). The assumption of ergodicity is crucial for predominant formalisations of economic dynamics as 'the ergodic case is much easier to handle mathematically', although in principle 'non-ergodicity is a necessary property of a mathematical model, if the model is supposed to describe trajectory occurrences of endogenous novelties and change' (ibid.).

\section{References}

Adkins, L. (2018) The Time of Money. Currencies, Stanford, California: Stanford University Press

Adrian, T. and Liang, N. (2016) Monetary Policy, Financial Conditions, and Financial Stability, Federal Reserve Bank of New York Staff Reports No. 690

Arrow, K.J. (1978) 'The Future and the Present in Economic Life', Economic Inquiry 16.2: $157-169$

Ayache,E. (2016) The Medium of Contingency: An InverseView of the Market, Basingstoke: Palgrave Macmillan

Baker, A. (2013) 'The New Political Economy of the Macroprudential Ideational Shift', New Political Economy 18.1: 112-139

Beckert, J. (2016) Imagined Futures: Fictional Expectations and Capitalist Dynamics, Cambridge, MA: Harvard University Press

- (2015) 'Re-Imagining Capitalist Dynamics. Fictional Expectations and the Openness of Economic Futures’, in P. Aspers and N. Dodd (eds) Re-Imagining Economic Sociology, Oxford: Oxford University Press: 57-78

Beckert, J. and Bronk, R. (2018) 'An Introduction to Uncertain Futures', in J. Beckert and R. Bronk, Uncertain Futures: Imaginaries, Narratives, and Calculation in the Economy, Oxford: Oxford University Press: 1-36

Black, F. and Scholes, M. (1973) 'The Pricing of Options and Corporate Liabilities', Journal of Political Economy 81.3: 637-654

Borio, C. and White, W.R. (2004) Whither Monetary and Financial Stability? The Implications of Evolving Policy Regimes, BIS Working Papers 147, Basel: Bank for International Settlements

Braun, B. (2018a) 'Central Banking and the Infrastructural Power of Finance: The Case of ECB Support for Repo and Securitization Markets', Socio-Economic Review, February, https://doi.org/10.1093/ser/mwy008

- (2018b) 'Central Bank Planning? Unconventional Monetary Policy and the Price of Bending the Yield Curve', in J. Beckert and R. Bronk (eds) Uncertain Futures: Imaginaries, Narratives, and Calculation in the Economy, Oxford: Oxford University Press: 31-37

- (2015) 'Governing the Future: The European Central Bank's Expectation Management during the Great Moderation', Economy and Society 44.3: 367-391

Braun, B. and Gabor, D. (2019) 'Central Banking, Shadow Banking, and Infrastructural Power', Preprint. SocArXiv https://doi.org/10.31235/osf.io/nf9ms

Bryan, D. and Rafferty, M. (2006) Capitalism with Derivatives: A Political Economy of Financial Derivatives, Capital and Class, Basingstoke and New York: Palgrave Macmillan

Butler, C. and Clews, R. (1997) Money Market Operations in the United Kingdom, BIS Conference Papers 3 (Implementation and Tactics of Monetary Policy), Basel: Bank for International Settlements 45-70 
Callon, M., Lascoumes, P. and Barthe, Y. (2009) Acting in an Uncertain World: An Essay on Technical Democracy, Inside Technology. Cambridge, MA: MIT Press

Carruthers, B.G. (2013) 'From Uncertainty Towards Risk: The Case of Credit Ratings', Socio-Economic Review 11.3: 525-551

Carruthers, B.G. and Stinchcombe,A.L. (1999) 'The Social Structure of Liquidity: Flexibility, Markets, and States', Theory and Society 28.3: 353-382

Christophers, B. (2017) 'The Performativity of the Yield Curve', Journal of Cultural Economy 10.1: $63-80$

Coombs, N. (2017) 'Macroprudential Versus Monetary Blueprints for Financial Reform', Journal of Cultural Economy 10.2: 207-216

Cooper, M. (2011) 'Complexity Theory After the Financial Crisis: The Death of Neoliberalism or the Triumph of Hayek?' Journal of Cultural Economy 4.4: 371-385

Davidson, P. (1982) 'Rational Expectations: A Fallacious Foundation for Studying Crucial Decision-Making Processes', Journal of Post Keynesian Economics 5.2: 182-198

Davis, G.F. (2009) Managed by the Markets: How Finance Reshaped America, New York: Oxford University Press

Espeland, W.N. and Stevens, M.L. (1998) 'Commensuration as a Social Process', Annual Review of Sociology 24.1:313-343

Esposito, E. (2004) 'The Arts of Contingency', Critical Inquiry 31.1: 7-25

Fligstein, N., Brundage, J.S. and Schultz, M. (2017) 'Seeing Like the Fed: Culture, Cognition, and Framing in the Failure to Anticipate the Financial Crisis of 2008', American Sociological Review 82.5: 879-909

Foucault, M. (2007)[1978] Security, Territory Population: Lectures at the Collège de France, 197778, Basingstoke and New York: Palgrave Macmillan

Gabor, D. (2016) 'The (Impossible) Repo Trinity: The Political Economy of Repo Markets', Review of International Political Economy 23.6: 967-1000

Gräbner, C. and Kapeller, J. (2015) 'New Perspectives on Institutionalist Pattern Modeling: Systemism, Complexity, and Agent-Based Modeling', Journal of Economic Issues 49.2: $433-440$

Hardie, I. and Howarth, D.J. (eds) (2013) Market-Based Banking and the International Financial Crisis, 1st edition, Oxford: Oxford University Press

Helleiner, E. (1994) States and the Reemergence of Global Finance: From Bretton Woods to the 1990s, Ithaca NY: Cornell University Press

Holmes, D.R. (2013) Economy of Words: Communicative Imperatives in Central Banks, Chicago: University of Chicago Press

Kirstein, M. (2015) 'From the Ergodic Hypothesis in Physics to the Ergodic Axiom in Economics', in Diskussionspapier 7. Wintertagung ICAE, Linz, 4-5 December 2015

Kluge, A., Evans, T. and Liebman, S. (1990) 'The Assault of the Present on the Rest of Time', New German Critique 49 (Winter): 11-22

Knight, F.H. (1921) Risk, Uncertainty and Profit, Boston and New York: Houghton Mifflin

Koselleck, R. (1989) Vergangene Zukunft, Frankfurt am Main: Suhrkamp

Krippner, G.R. (2011) Capitalizing on Crisis: The Political Origins of the Rise of Finance, Cambridge, MA: Harvard University Press

- (2005) 'The Financialization of the American Economy', Socioeconomic Review 3.2: $173-208$

Langenohl, A. (2018) 'Sources of Financial Synchronism: Arbitrage Theory and the Promise of Risk-Free Profit', Finance and Society 4.1: 26-40

— (2007) Finanzmarkt Und Temporalität: Imaginäre Zeit Und Die Kulturelle Repräsentation Der Gesellschaft, Qualitative Soziologie, Stuttgart: Lucius \& Lucius 
Langenohl,A. and Wetzel, D.J. (2011) 'Finanzmärkte Und Ihre Sinnformen: Handlungskoord ination Und Signalkommunikation’, Berliner Journal Für Soziologie 21: 539-559

Law, J. and Urry, J. (2004) 'Enacting the Social', Economy and Society 33.3: 390-410

LiPuma, E. (2017) The Social Life of Financial Derivatives: Markets, Risk, and Time, Durham: Duke University Press

Lombardelli, C. and Saleheen, J. (2003) 'Public Expectations of UK Inflation', Bank of England Quarterly Bulletin, Autumn 2003: 281-290

Luhmann, N. (1976) 'The Future Cannot Begin: Temporal Structures in Modern Society', Social Research 43.1: 130-152

MacKenzie, D. (2004) 'The Big, Bad Wolf and the Rational Market: Portfolio Insurance, the 1987 Crash and the Performativity of Economics', Economy and Society 33.3: 303-334

MacKenzie, D. and Millo, Y. (2003) 'Constructing a Market, Performing Theory: The Historical Sociology of a Financial Derivatives Exchange', American Journal of Sociology 109.1: 107-145

Mallaby, S. (2017) The Man Who Knew: The Life and Times of Alan Greenspan, London: Bloomsbury

Marglin, S.A. and Schor, J.B. (eds) (2000) The Golden Age of Capitalism: Reinterpreting the Postwar Experience, reprinted, WIDER Studies in Development Economics, Oxford: Clarendon Press

McGoey, L. (2012) 'Strategic Unknowns: Towards a Sociology of Ignorance', Economy and Society 41.1: 1-16

Mehrling, P. (2011) The New Lombard Street: How the Fed Became the Dealer of Last Resort, Princeton, NJ: Princeton University Press

Minsky, H. (1980) 'Capitalist Financial Processes and the Instability of Capitalism', Journal of Economic Issues 14.2: 505-523

Montagne, S. (2009) 'Short-Termism as a Rule: The Effects of Portfolio Management Delegation', Revue d'économie Financière 9 (Hors-Série: Sovereign Wealth Funds): 381-395

Murau, S. (2017) 'Shadow Money and the Public Money Supply: The Impact of the 20072009 Financial Crisis on the Monetary System', Review of International Political Economy 24.5: 802-838

Nesvetailova, A. (2015) 'A Crisis of the Overcrowded Future: Shadow Banking and the Political Economy of Financial Innovation', New Political Economy 20.3: 431-453

- (2007) Fragile Finance: Debt, Speculation and Crisis in the Age of Global Credit, Basingstoke and New York: Palgrave Macmillan

Peters, O. (2019) 'The Ergodicity Problem in Economics', Nature Physics 15.12: 1216-1221

Star, S.L. and Ruhleder, K. (1996) 'Steps Toward an Ecology of Infrastructure: Design and Access for Large Information Spaces', Information Systems Research 7.1: 111-134

Stockhammer, E. (2008) 'Some Stylized Facts on the Finance-Dominated Accumulation Regime', Competition \& Change 12.2: 184-202

Taleb, N.N. (2007) The Black Swan: The Impact of the Highly Improbable, 1st edition, New York: Random House

van der Zwan, N. (2014) 'Making Sense of Financialization', Socio-Economic Review 12.1: 99-129

Walter, J.R. (2006) 'The 3-6-3 Rule: An Urban Myth?’ Economic Quarterly 92.1: 51-78

Walter, T. and Wansleben, L. (2019) 'How Central Bankers Learned to Love Financialization: The Fed, the Bank, and the Enlisting of Unfettered Markets in the Conduct of Monetary Policy', Socio-Economic Review, March, https://doi.org/10.1093/ ser/mwz011 


\section{Timo Walter and Leon Wansleben}

Wansleben, L. (2018) 'How Expectations Became Governable: Institutional Change and the Performative Power of Central Banks', Theory and Society 47.6: 773-803

Watson, M. (2007) 'Searching for the Kuhnian Moment: The Black-Scholes-Merton Formula and the Evolution of Modern Finance Theory', Economy and Society 36.2: 325-337

Woodford, M. (2009) 'Convergence in Macroeconomics: Elements of the New Synthesis', American Economic Journal: Macroeconomics 1.1: 267-279

Zaloom, C. (2009) 'How to Read the Future: The Yield Curve, Affect, and Financial Prediction', Public Culture 21.2: 245-268 